\title{
DEVIL'S CLAW: ACTION ON THE CENTRAL NERVOUS SYSTEM ${ }^{1}$
}

\author{
GARRA DO DIABO: AÇÃO NO SISTEMA NERVOSO CENTRAL
}

\section{Valtieri Bortoluzzi de Lima ${ }^{2}$, Mariana Fernandes Ribeiro ${ }^{3}$, Cristiane Köhler Carpilovsky ${ }^{4}$, Paula Köhler Carpilovsky ${ }^{5}$ Luciana Maria Fontanari Krause ${ }^{6}$}

\begin{abstract}
The Harpagophytum procumbens (HP), popularly known as "garra do diabo" is a native plant from Africa that has been used for years by traditional medicine for treating a various number of health conditions, among which the inflammatory disturbances stand out. The potential anti-inflammatory and antioxidant effects of the plant stand out since it has in its chemical matrix several bioactive compounds. However, there's still little research that reports the association of HP on the central nervous system (CNS). The objective of this paper was to perform a review of the literature among the assays already described in the literature, in Portuguese and English, using the HP associated with the prevention and treatments of neurological and/or neuropsychiatry disturbances and conditions. The methodology performed is a review of the literature bringing publishes of papers found in the virtual database PubMed, using the descriptors: Harpagophytum procumbens (HP) and Central Nervous System (CNS). In total, 11 articles reported the effects of HP with performance on the CNS. In conclusion, this study reported, in association with previous ones, that the antioxidant action of the HP may be related to neuroprotective results due to a synergism of phenolic glycosylated derivatives such as verbascoside and/or iridoid glycosides such as harpagoside and flavonoids.
\end{abstract}

Keywords: Central Nervous System, Devil's Claw, Neuroscience.

\section{RESUMO}

A Harpagophytum procumbens (HP), popularmente conhecida como "garra do diabo" é uma planta nativa da Africa que tem sido utilizada há anos pela medicina tradicional tratar uma ampla gama de condições de saúde, dentre essas se destacam os distúrbios inflamatórios. O potencial efeito anti-inflamatório e antioxidante da planta se destaca já que a mesma possui em sua matriz química diversos compostos bioativos. No entanto, ainda há poucos estudos que relatam a associação da HP no sistema nervoso central (SNC). O objetivo desse estudo foi realizar uma revisão de literatura acerca dos ensaios já descritos na literatura utilizando a HP associada à prevenção e tratamentos de distúrbios e condições neurológicas elou neuropsiquiátricos. A metodologia realizada é uma revisão de literatura trazendo publicações de trabalhos encontrados na base de dados virtual PubMed, utilizando os descritores: Harpagophytum procumbens. No total 11 artigos relatam os efeitos da HP com atuação no SNC. Em conclusão, este estudo relatou, em associação com os anteriores, que a ação antioxidante do HP pode estar relacionada a resultados neuroprotetores devido à um sinergismo de derivados glicosilados fenólicos tais como verbascosídeo elou glicosilados iridoides como o harpagosídeo e flavonoids.

Palavras-chave: Sistema Nervoso Central, Garra do Diabo, Neurociência.

\footnotetext{
${ }^{1}$ Pesquisa realizada no Curso de Mestrado em Ciências da Saúde e da Vida.

${ }^{2}$ Mestre em Ciências da Saúde e da Vida - UFN. E-mail: val_bortoluzzi@hotmail.com

${ }^{3}$ Mestranda do Programa de Pós Graduação em Nanociências - UFN. E-mail: marianah-fr@hotmail.com

${ }^{4}$ Professora do Departamento de Morfologia da Universidade Federal de Santa Maria - UFSM. E-mail: criscarpila@gmail.com

${ }^{5}$ Acadêmica do curso de Medicina da Universidade Franciscana - UFN. E-mail: kohlerc.paula@gmail.com

${ }^{6}$ Professora Colaboradora do Curso de Mestrado em Ciências da Saúde e da Vida e orientadora do projeto - UFN; Professora Adjunta do Departamento de Morfologia da UFSM. E-mail: 1fontanari@yahoo.com.br
} 


\section{INTRODUCTION}

The Harpagophytum is a perennial herbaceous plant, native from South Africa, that belongs to the Pedaliaceae family, and its growth occurs especially in the Kalahari Desert and the steppes of Namibia (NAKAZAWA et al., 2012). It has a characteristic shape due to the appearance of a claw at the end of its fruit, being popularly known as "garra do diabo". Traditional medicine uses this plant for a wide range of treatments and/or disease control, such as indigestion, fevers relief, allergic reactions, rheumatism, among others (VAN WYK; GERICKE, 2000; MAHOMED; OJEWOLE, 2004; MENGHINI et al., 2019).

Due to its therapeutic action, especially its anti-inflammatory and analgesic actions, the commercialization of HP is released in many countries, while in the United Kingdom, Holland, United States and in the Far East it is registered as a food supplement, in Germany and France its trade is as herbal medicine (STEWART; COLE, 2005). In Brazil, in the year of 2011, HP was released as herbal medicine by the National Health Surveillance Agency (ANVISA) and is indicated for relief of moderate joint pain and acute back pain. Although the popular name of the plant is derived from the appearance of its fruits, the medicinal properties are derived from the secondary tuberous roots (NAKAZAWA et al., 2012).

Phytochemical studies have already isolated several constituents of this plant, elucidating well its chemical composition, with iridescent glycosides, such as harpagoside, harpagida and procumbid being the main components (GEORGIEV et al., 2013). Among them, harpagoside acts as a relevant chemical quality marker and bioactive compound of HP (GRANT et al., 2007). Additional constituents include amino acids, carbohydrates, flavonoids, aromatic acids, phytosterols, triterpenes, phenolic glycosylated derivatives such as verbascoside and acteoside/isoacteoside, monosaccharides and oligosaccharides (ANAUATE; TORRES; DE MELLO, 2010).

However, it is known that the therapeutic action of HP is not exclusively due to the presence of harpagoside, but may also be associated with other glycosylated iridoids and other components, which may antagonize or potentialize its effect (KASZKIN et al., 2004; GEORGIEV et al., 2013). The anti-inflammatory and anti-rheumatic activity of this plant was primarily reported from positive results in studies performed with the harpagoside, which showed a significant decrease in formaldehyde-induced arthritis in rats (EICHLER; $\mathrm{KOCH}, 1970)$.

Of particular importance, in the literature there are still few studies on the action of HP in the central nervous system (CNS), therefore, our goal was to conduct a literature review on studies that demonstrate results with HP in the CNS, especially in models of neurological and/or neuropsychiatric diseases. Nonetheless, the plant know as Devil's Claw has shown important anti-oxidative and antiinflammatory actions regarding the central nervous system, due to the effect of its compounds, such as iridoid glycosides and phenolic glycosylated. 


\section{METHODOLOGY}

This study is a literature review. The following descriptors were used to select the articles: Harpagophytum procumbens and/or central nervous system. The inclusion criteria used to search publications were: articles with texts available in Portuguese and English. The exclusion criteria were bibliographic review publications and articles that did not address the proposed theme regarding the action of the devil's claw on the central nervous system.

\section{RESULTS AND DISCUSSIONS}

One of the first studies addressing the action of HP in the CNS was by Bhattacharya and Bhattacharya (1998) demonstrating that rats treated with HP, showed an increase in the activity of antioxidant enzymes in the brain, such as superoxide dismutase (SOD), catalase (CAT) and glutathione peroxidase (GSH-px), in addition to decreasing the lipid peroxidation already existing in the cortex and striated.

In addition, another in vitro study demonstrated that the raw extract and several fractions of HP, especially the ethyl acetate fraction (FAE HP), guaranteed protection against oxidative damage in the brain of rats and loss of cell viability induced by different prooxidants (Fe2+ and Sodium Nitroprusside), as well as HP EAF demonstrated greater antioxidant effects and decreased lipid peroxidation and cellular damage, where the authors suggested that the plant's antioxidant action may be related to its anti-inflammatory activity (SCHAFFER et al., 2013).

Later, Schaffer and collaborators (2016) demonstrated the beneficial action of HP EAF in reducing movement disorders induced by chronic administration of antipsychotic (fluphenazine) in rodents in a model of orofacial dyskinesia, and this effect seems to be related to the antioxidant and anti-inflammatory activity of this fraction. Fluphenazine induced oxidative damage in the cortex and striated (CAT activity and reactive oxygen species), while the HP EAF protected against this damage especially in the striated, while in the cortex, the HP EAF protected only against CAT activity. Finally, they concluded that the HP EAF may be a promising therapeutic agent in the treatment of involuntary oral movements.

Geogiev and collaborators (2012) used the HP extract and the verbascoside component to evaluate the inhibition of acetylcholinesterase (AChe) and butylcholinesterase (BChe) and also the antioxidant activity in iron-related systems in in vitro experiments determined by electro photometric methods. The results indicated that fractions of phenylethanoid glycosides present in the plant showed a potent anti-inflammatory power in addition to the inhibitory power of AChe and BChe. In the same proposal, Bae and collaborators (2014) evaluated cholinesterase inhibition from HP root extract. The inhibitory activities of $\mathrm{AChe}$ and $\mathrm{BChE}$ were measured by the spectrophotometric method indicating 
that the extract showed inhibitory effects, which suggests that the plant has great potential in the treatment of diseases such as Alzheimer's.

In this context, Ferrante and collaborators (2017) investigated the protective effect of HP aqueous extract through microwaves in rat hypothalamic cells (Hypo-E22) and in rat cortex in a peptide-induced Alzheimer's model $\beta$-amyloid. Malondialdehyde (MDA) levels, a marker of brain oxidative stress and lipid peroxidation, neurotrophic factor, tumor necrosis factor (TNF- $\alpha$ ), 3-hydroxyquinurenine (3-HK), as well as dopamine, norepinephrine and serotonin levels in the cortex were measured. The study showed that the microwave-assisted system with aqueous extract of HP was well tolerated by Hypo-E22 cells in the range of $10-50 \mu \mathrm{g} / \mathrm{mL}$, but there was a significant decrease in cell viability in the range of 100-200 $\mu \mathrm{g} / \mathrm{mL}$. The cells were also well tolerated by the neurotrophic factor while there was a negative expression of TNF- $\alpha$. Above all, the HP extract decreased stimulation of the peptide $\beta$ - peptide of MDA and 3-HK and there was also a decrease of dopamine, noradrenaline, and serotonin in the cortex. In conclusion, the extract was effective in reducing oxidative stress and reducing monoamine signaling in the cortex.

In addition, Li and collaborators (2015) demonstrated that treatment with intrahippocampal injected harpagoside had neuroprotective effects in rats injected with peptide $\beta$-amyloid in an Alzheimer's model, improving learning and memory deficit, as well as pre-treatment with harpagoside significantly attenuated the decrease in cell viability in primary lesions with A $\beta 1-42$ in culture with cortical neurons.

Recently, Ungerer et al. (2020) used a model of contusion in rodents, causing a spinal cord injury in order to assess the action of HP on locomotor function, responses to stimuli, and neurochemical changes. Furthermore, they used in vitro tests simultaneously using microglias (BV-2) to confirm the anti-inflammatory and antioxidant effects of the extract. The treatment performed with HP showed marked improvement in locomotor function, increasing sensitivity to mechanical stimuli. It also revealed that HP suppressed oxidative stress and inflammatory responses, including nitric oxide production, reactive oxygen species, and phosphorylation of A2 cytosolic phospholipases, in addition to the positive regulation of the oxidative stress caused.

Peruru and collaborators (2020) evaluated the efficacy of HP against arsenic-induced neurotoxicity in female rats by observing through various parameters the behavioral changes. It was possible to notice that treatment with HP improved anxiety and motor coordination in rats compared to the control group, besides reducing the oxidative stress caused by arsenic, the results were especially corroborated with the concentration of harpagoside in the serum of the animals.

Mahomed and Ojewole (2006) evaluated the anticonvulsant activity of HP aqueous extract in an in vivo model using seizure-induced rats with pentilenotetrazol, picrotoxin, and bicuculin, using fenorbabitone and diazepam as reference anticonvulsants. The results showed that HP extract inhibited and/or attenuated the convulsions induced by drugs, delaying the onset of the convulsions induced by 
pentylenetetrazol and decreasing the duration of the seizures, as well as interfering with GABAergic neurotransmission, which was increased in the brain.

In another in vivo study, Chen and collaborators (2018) evaluated the neuroprotective effect of harpagoside in rats with chronic cerebral hypoperfusion in a model of vascular dementia, evaluating the learning capacity through memory tests. The animals were divided into groups and exposed to several trials that evaluated their motor capacity together with the administration during two months of harpagoside. This chronic administration proved capable of restoring learning and fear memory. In addition, the harpagoside was able to significantly suppress the activity of PTEN and Akt / GSK-3ß, proving to be a potential therapeutic drug directed at cognitive deficiencies of vascular dementia (table 1).

Table 1. Experimental studies involving Harpagophytum procumbens and neurological function

\begin{tabular}{|c|c|c|c|c|}
\hline Type of survey & Goal & Reply & Doses & Reference \\
\hline In vivo & Evaluate HP antioxidant activity & $\begin{array}{l}\text { Increased antioxidant enzymes } \\
\text { in the cortex and striated rats and } \\
\text { decreased lipid peroxidation. }\end{array}$ & $100-200 \mathrm{mg} / \mathrm{kg}(\mathrm{HP})$ & $\begin{array}{c}\text { Bhattacharya; } \\
\text { Bhattacharya, } 1998\end{array}$ \\
\hline In vivo & $\begin{array}{l}\text { Investigate the anticonvulsant } \\
\text { activity of HP aqueous extract in a } \\
\text { convulsion model in rats. }\end{array}$ & $\begin{array}{l}\text { Decrease of seizures through } \\
\text { the probable increase of GABA- } \\
\text { transmission and/or facilitating } \\
\text { GABA-action in the brain, HP also } \\
\text { depressed the CNS }\end{array}$ & $\begin{array}{c}100,200,400 \\
800 \mathrm{mg} / \mathrm{kp}(\mathrm{HP})\end{array}$ & $\begin{array}{c}\text { Mahomed; } \\
\text { Ojewole; } 2006\end{array}$ \\
\hline In vitro & $\begin{array}{l}\text { Assess acetylcholinesterase (AChe) } \\
\text { and butylcholinesterase (BChe) in- } \\
\text { hibition and HP antioxidant activity }\end{array}$ & $\begin{array}{l}\text { Anti-inflammatory effect and inhi- } \\
\text { bitory power of AChe and BChe. }\end{array}$ & $\begin{array}{l}50,100,200 \mu \mathrm{g} / \mathrm{mL} \\
\text { (HP extracts and } \\
\text { verbascosid) }\end{array}$ & Geogiev et al., 2012 \\
\hline In vitro & $\begin{array}{l}\text { To evaluate the effect of extracts } \\
\text { and fractions of HP on prooxi- } \\
\text { dant induced lipid peroxidation } \\
\text { (brain homogenate) }\end{array}$ & $\begin{array}{l}\text { All HP extracts inhibited lipid } \\
\text { peroxidation. FAE HP major anti- } \\
\text { oxidant effects, inhibition of lipid } \\
\text { peroxidation and decreased damage }\end{array}$ & $\begin{array}{c}100,200,400 \mu \mathrm{g} / \mathrm{mL} \\
\text { (ethyl acetate } \\
\text { fraction HP) }\end{array}$ & Schaffer et al., 2013 \\
\hline In vitro & $\begin{array}{l}\text { Evaluate acetylcholinesterase } \\
\text { (AChe) and butylcholinesterase } \\
\text { (BChe) inhibition. }\end{array}$ & $\begin{array}{l}\text { Inhibitory effect of AChe and } \\
\text { BChe. }\end{array}$ & $\begin{array}{c}100 \mu \mathrm{g} / \mathrm{mL} \text { (ethyl } \\
\text { acetate fraction HP) }\end{array}$ & Bae et al., 2014 \\
\hline $\begin{array}{l}\text { In vitro and } \\
\text { In vivo }\end{array}$ & $\begin{array}{l}\text { Elucidate the effect of harpagoside } \\
\text { on peptide-induced neurodegenera- } \\
\text { tion } \beta \text { - amyloid and the underlying } \\
\text { molecular mechanism. }\end{array}$ & $\begin{array}{l}\text { The harpagoside has demonstrated } \\
\text { a neuroprotective effect improving } \\
\text { learning and memory deficit in rats } \\
\text { in the Alzheimer's model. }\end{array}$ & $\begin{array}{c}5 \mathrm{mg} / \mathrm{kg}+15 \mathrm{mg} / \mathrm{kg} \\
\text { (harpagoside) }\end{array}$ & Li et al., 2015 \\
\hline In vivo & $\begin{array}{l}\text { To investigate the effect of ethyl } \\
\text { acetate HP (FAE HP) fraction } \\
\text { on fluflenazin-induced orofacial } \\
\text { dyskinesia in rats }\end{array}$ & $\begin{array}{l}\text { HP EAF has proven effective } \\
\text { in protecting some behavioral } \\
\text { changes induced by fluflenazine, as } \\
\text { well as being able to reverse oxida- } \\
\text { tive damage. }\end{array}$ & $\begin{array}{l}30 \mathrm{mg} / \mathrm{kg} \text { (ethyl } \\
\text { acetate fraction } \mathrm{HP} \text { ) }\end{array}$ & Schaffer et al., 2016 \\
\hline
\end{tabular}




\begin{tabular}{|c|c|c|c|c|}
\hline In vivo & $\begin{array}{l}\text { To investigate the neuroprotective } \\
\text { effect of harpagoside in rats with } \\
\text { chronic cerebral hyporperfusion in } \\
\text { a vascular dementia model. }\end{array}$ & $\begin{array}{c}\text { Harpagoside was able to restore } \\
\text { learning (spatial memory and fear), } \\
\text { suppress the activity of PTEN and } \\
\text { Akt / GSK-3ß. }\end{array}$ & $15 \mathrm{mg} / \mathrm{kg}$ (harpagoside) & Chen et al., 2018 \\
\hline $\begin{array}{l}\text { In vivo and } \\
\text { In vitro }\end{array}$ & $\begin{array}{l}\text { To evaluate locomotor function } \\
\text { and responses to stimuli in a spinal } \\
\text { cord injury (LMS) model and } \\
\text { neurochemical changes associated } \\
\text { with allodynia in LMS. }\end{array}$ & $\begin{array}{l}\text { Improved locomotor function and } \\
\text { increased sensitivity to mechanical } \\
\text { stimuli. Anti-inflammatory and an- } \\
\text { tioxidant effect on microbial cells. }\end{array}$ & $300 \mathrm{mg} / \mathrm{kg}$ (HP) & Ungerer et al., 2020 \\
\hline In vivo & $\begin{array}{c}\text { To investigate the neuroprotective } \\
\text { efficacy of HP against arsenic- } \\
\text { induced neurotoxicity in rats. }\end{array}$ & $\begin{array}{l}\text { Improved anxiety, motor coordina- } \\
\text { tion and decreased oxidative stress. }\end{array}$ & $200-400 \mathrm{mg} / \mathrm{kg}$ (HP) & Peruru et al., 2020 \\
\hline
\end{tabular}

Source: Author's construction

\section{CONCLUSION}

HP has been of study interest for a wide range of diseases, especially those in the inflammatory field. However, attention has grown to this plant in disease models that are related to CNS and neurotransmitters. According to the literature, HP has been shown to interact beneficially in the brain field, possibly due in large part to its already well elucidated anti-inflammatory action. In addition, some studies demonstrate that the neuroprotective results may be related to the antioxidant action of this plant due to a synergism of iridoid glycosides such as harpagoside and flavonoids and/or phenolic glycosylated derivatives such as verbascoside.

Added to the results in the literature, the studies support further research with $\mathrm{PH}$ in the treatment of neurological diseases, as well as in disorders involving cognitive and behavioral deficits. However, there are still few standardizations in the literature about the use of this plant as doses and the mechanisms of action of how it can interact in the cerebral pathways. Therefore, further studies are suggested to evaluate the mechanisms by which $\mathrm{PH}$ acts, especially modulating and protecting the $\mathrm{CNS}$, as well as the main components involved in this action.

\section{REFERENCES}

ANAUATE, M. C.; TORRES, L. M.; DE MELLO, S. B.V. Effect of isolated fractions of Harpagophytum procumbens DC (devil's claw) on COX1, COX2 activity and nitric oxide production on whole blood assay. Phytotherapy research, v. 24, n. 9, p. 1365- 1369, 2010.

BAE, Y. H. et al. Cholinesterase inhibitors from the roots of Harpagophytum procumbens. Archives of pharmacal research, v. 37, n. 9, p. 1124-1129, 2014. 
BHATTACHARYA, A.; BHATTACHARYA, S. K. Anti-oxidant activity of Harpagophytum procumbens (devil's claw). British journal of phytotherapy, v. 5, n. 2, p. 68-71, 1998.

CHEN, C. et al. Harpagoside rescues the memory impairments in chronic cerebral hypoperfusion rats by inhibiting PTEN activity. Journal of Alzheimer's Disease, v. 63, n. 2, p. 445-455, 2018.

EICHLER, O.; KOCH, C. Antiphlogistic, analgesic and spasmolytic effect of harpagoside, a glycoside from the root of Harpagophytum procumbens DC. Arzneimittel-Forschung, v. 20, n. 1, p. 107-109, 1970.

FERRANTE, C. et al. Protective effects induced by microwave assisted aqueous Harpagophytum extract on rat cortex synaptosomes challenged with amyloid $\beta$-peptide. Phytotherapy Research, v. 31, n. 8, p. 1257-1264, 2017.

GEORGIEV, M. I. et al. Harpagoside: from Kalahari Desert to pharmacy. Phytochemistry, v. 92 , p. 8-15, 2013.

GEORGIEV, M. I.; ALIPIEVA, K.; ORHAN, I. E. Cholinesterases inhibitory and antioxidant activities of Harpagophytum procumbens from in vitro systems. Phytotherapy Research, v. 26, n. 2, p. 313-316, 2012.

GRANT, L. et al. A review of the biological and potential therapeutic actions of Harpagophytum procumbens. Phytotherapy Research, v. 21, n. 3, p. 199-209, 2007.

KASZKIN, M. et al. Downregulation of iNOS expression in rat mesangial cells by special extracts of Harpagophytum procumbens derives from harpagoside-dependent and independent effects. Phytomedicine, v. 11, n. 7-8, p. 585-595, 2004.

LI, J. et al. Harpagoside ameliorates the amyloid- $\beta$-induced cognitive impairment in rats via up-regulating BDNF expression and MAPK/PI3K pathways. Neuroscience, v. 303, p. 103-114, 2015.

MAHOMED, I. M.; OJEWOLE, J. A. Analgesic, antiinflammatory and antidiabetic properties of Harpagophytum procumbens DC (Pedaliaceae) secondary root aqueous extract. Phytotherapy Research, v. 18, n. 12, p. 982-989, 2004.

MAHOMED, I. M.; OJEWOLE, J. AO. Anticonvulsant activity of Harpagophytum procumbens DC [Pedaliaceae] secondary root aqueous extract in mice. Brain Research Bulletin, v. 69, n. 1, p. 57-62, 2006. 
MENGHINI, L. et al. Devil's claw (Harpagophytum procumbens) and chronic inflammatory diseases: A concise overview on preclinical and clinical data. Phytotherapy Research, v. 33, n. 9, p. 2152-2162, 2019.

NAKAZAWA, K. et al. GABAergic interneuron origin of schizophrenia pathophysiology. Neuropharmacology, v. 62, n. 3, p. 1574-1583, 2012.

PERURU, R. et al. Devil's claw (Harpagophytum procumbens) ameliorates the neurobehavioral changes and neurotoxicity in female rats exposed to arsenic. Heliyon, v. 6, n. 5, p. e03921, 2020.

SCHAFFER, L. F. et al. Harpagophytum procumbens ethyl acetate fraction reduces fluphenazine-induced vacuous chewing movements and oxidative stress in rat brain. Neurochemical Research, v. 41 , n. 5 , p. $1170-1184,2016$.

SCHAFFER, L.F. et al. Harpagophytum procumbens prevents oxidative stress and loss of cell viability in vitro. Neurochemical Research, v. 38, n. 11, p. 2256-2267, 2013.

STEWART, K. M.; COLE, D. The commercial harvest of devil's claw (Harpagophytum spp.) in southern Africa: The devil's in the details. Journal of ethnopharmacology, v. 100, n. 3, p. 225-236, 2005.

UNGERER, G. et al. Harpagophytum procumbens extract ameliorates allodynia and modulates oxidative and antioxidant stress pathways in a rat model of spinal cord injury. Neuromolecular Medicine, p. 1-15, 2020.

VAN WYK. B. E, GERICKE, N. People's plants: A guide to useful plants of Southern Africa. Briza publications, 2000. 